\title{
Effect of Drying Methods on the Physico-chemical Characteristics and Antioxidant Capacity of Taro, Sweetpotato, Stevia and Malunggay Leaves
}

\author{
Inish Chris P. Mesias*, Daniel Leslie S. Tan and Benjamin L. Cinto, Jr.
}

\begin{abstract}
Fresh leaves are sensitive to high temperature so that appropriate drying method should be selected to dry leaves. This study aimed to determine the effect of drying methods on the physico-chemical characteristics and antioxidant capacity of taro (Colocasia esculenta), sweetpotato (Ipomea batatas), stevia (Stevia rebaudiana), and malunggay (Moringa oleifera) leaves. Fresh, healthy and mature leaves of taro, sweetpotato, stevia, and malunggay were subjected to solar drying, mechanical drying, and sun drying. The parameters evaluated in this study included moisture content, rehydration ratio, bulk density, water activity, total chlorophyll, antioxidant capacity, and non-enzymatic browning. Results showed that solar drying obtained the highest moisture removal capacity, rehydration ratio and water activity reduction while sun drying had the least. However, it was also with solar drying that the degree of non-enzymatic browning was the highest. Minimum bulk density was attained using solar and mechanical drying. In terms of chlorophyll content, mechanical drying had the highest. No apparent difference at $p<0.05$ between solar and sun drying methods was observed in terms of their effects on chlorophyll retention and antioxidant capacity. Variable effects of the different drying methods include little or no change, significant declines or enhancement of the leaves' physico-chemical and antioxidant attributes.
\end{abstract}

Keywords: drying methods, antioxidant capacity, taro, sweet potato, stevia, malunggay

\section{INTRODUCTION}

Leaves of taro (iniito), sweet potato (sp30), malunggay and stevia are recognized as healthy food materials considering their abundant antioxidant components and nutritional properties. Kaushal (2013) reported taro leaves as rich sources of $\beta$-carotene, ascorbic acid, folic acid, riboflavin and minerals (iron, calcium, phosphorus). Sweet potato leaves are known as excellent sources of antioxidative polyphenolics, vitamins and minerals (Islam 2006).

Philrootcrops, Visayas State University, Baybay City, Leyte

*Corresponding Author. Address: Philrootcrops, Visayas State University, Baybay City, Leyte 6521-A Philippines.E-mail:inishchris.mesias@vsu.edu.ph

DOI: $10.32945 /$ atr3928.2017 
Stevia on the other hand is recognized for its high content of sweet components, flavonoids, alkaloids, chlorophylls, xantophylls, oligosaccharides, free sugars, amino acids, lipids and trace elements (Gisleine et al 2006). Fahey (2005) reported high amount of $\beta$-carotene, Vitamin $\mathrm{C}$, protein, iron, potassium, calcium and phosphorus in malunggay leaves.

In spite of the nutritional potential of these leaves, their inherent high moisture content renders them perishable at ambient conditions. Hence, drying techniques were employed to enhance shelf life and availability. With drying, moisture content of food material is reduced preventing microbial growth, minimizing microbial degradation and consequently permitting shelf-life extension (Doymaz 2011). The reduction of the bulk of the fresh material is congruent to the reduction of packaging, storage and transportation costs. Severe drying process, nevertheless, corresponds to higher nutritional loss and poorer organoleptic and physicochemical properties. With this, there is an increasing interest in the development of new and more efficient drying methods. Efficacy and efficiency of drying designs necessitate more profound knowledge of the changes in the properties of foods that occur with drying process. The drying process basically causes structural deformations of food materials thus modifications of their physico-chemical and nutritional properties. Understanding these changes as affected by different drying methods is therefore of great importance.

\section{MATERIALS AND METHODS}

\section{Sample Preparation}

Fresh, healthy and mature leaves of taro, sweet potato, stevia, and malunggay were harvested from the experimental field of Philippine Root Crop Research and Training Center, Visayas State University, Visca, Baybay City, Leyte. The leaves were thoroughly washed with water to remove all adhering dust and dirt, drained and then divided into three portions for the three different drying processes.

\section{Drying Processes}

Leaf samples were subjected to three different drying methods: open-air sun drying, direct solar drying, and mechanical drying.

Solar Drying (SOD). A direct solar dryer was used for solar drying the leaf samples. Samples with known moisture content were placed in stainless steel trays with wire mesh at the bottom and dried for two days. Temperature and relative humidity were closely monitored and recorded.

Sun Drying (SUD). In the open air sun drying method, samples were spread on the stainless steel trays in a single layer directly exposed to sunlight. Samples were dried for two days. Temperature and relative humidity were also recorded.

Mechanical Drying (MED). The oven was pre-heated to $50^{\circ} \mathrm{C}$ and the leaf samples were loaded in the stainless steel trays and dried for 8 hours.

\section{Moisture Content Determination}

Leaf samples of about 1 gram each were prepared for the analysis. Sampling errors were reduced by taking large samples, mixing well and taking smaller subsample for analysis. Moisture content of the leaves was determined using a 
Effect of Drying Methods on the Physico-chemical Characteristics

laboratory oven kept at $105^{\circ} \mathrm{C}$ for 24 hours (AOAC 1990). Triplicate determinations were made and the moisture content was calculated on a dry basis using the formula:

$$
\begin{aligned}
& M C(\text { dry basis })=\frac{W_{i}-W_{b}}{W_{b}} \times 100 \\
& \text { where: } \quad M C=\text { moisture content (\%) } \\
& \mathrm{W}_{\mathrm{i}} \text { =initial weight }(\mathrm{g}) \text { of samples } \\
& \mathrm{W}_{\mathrm{b}} \text { =bone dry weight }(\mathrm{g})
\end{aligned}
$$

\section{Rehydration Ratio Assessment}

The method of Ranganna (1992) was used in the assessment of the rehydration ratio. Approximately 2 grams of the dried sample were placed in a $250 \mathrm{~mL}$ laboratory glass. Distilled water $(150 \mathrm{~mL})$ was added and the glass was covered and heated to boil within 3 minutes. The content of the laboratory glass was then gently boiled for 10 more minutes and then cooled. The cooled content was filtered and weighed. The rehydration ratio was calculated as:

$$
R R=\frac{W_{r}}{W_{d}}
$$

where: $\quad W_{r} r$ drained weight (g) of the rehydrated sample

$W d$ =weight of the dry sample used for rehydration

\section{Bulk Density}

Bulk density of the dried leaves was obtained by measuring the volume of a determined weight of the powder form of the leaves in a $100 \mathrm{~mL}$ graduated glass cylinder.

\section{Non-Enzymatic Browning (NEB)}

The increase in the absorbance of the sample extract at $420 \mathrm{~nm}$ wavelengths was taken as a measure of non-enzymatic browning (Negi \& Roy 2001). Five grams of each of the dried leaf samples were soaked in $100 \mathrm{~mL}$ of $60 \%$ alcohol for 12 hours and filtered. Absorbance of the filtrate was recorded at $420 \mathrm{~nm}$ using UV-Vis spectrophotometer with $60 \%$ alcohol as blank. Absorbance reading was expressed in terms of optical density (Ranganna 1986).

\section{Spectrophotometric Determination of Total Chlorophyll}

The method of Kaushal (2013) was followed in determining the total chlorophyll content of the dried leaf samples. Major veins and any tough, fibrous tissue were discarded. The leaf samples were pulverized. Leaf homogenate was prepared by mixing about $100 \mathrm{mg}$ of pulverized leaf sample with $10 \mathrm{~mL}$ of $80 \%$ acetone. The leaf homogenate was filtered using filter paper. The retentate was discarded and the extract (filtrate) was collected. Absorbance measurements of 
the extract at 645 and $663 \mathrm{~nm}$ were determined using UV-vis spectrophotometer. The total chlorophyll content was estimated using Arnon's equations:

$$
\begin{aligned}
& \text { Chlorophylla }\left(\mathrm{mgg}^{-1}\right)=\left[\left(12.7 \times \mathrm{A}_{663}\right)-\left(2.6 \times \mathrm{A}_{645}\right)\right] \times \frac{\mathrm{mL} \text { acetone }}{\mathrm{mg} \text { leaf tissue }} \\
& \text { Chlorophyll b }\left(\mathrm{mg} \mathrm{g}^{-1}\right)=\left[\left(12.7 \times \mathrm{A}_{645}\right)-\left(4.68 \times \mathrm{A}_{663}\right)\right] \times \frac{\mathrm{mL} \text { acetone }}{\mathrm{mg} \text { leaf tissue }}
\end{aligned}
$$

Total chlorophyll $\left(\mathrm{mg} \mathrm{g}^{-1}\right)=$ chlorophyll $\mathrm{a}+$ chlorophyll $\mathrm{b}$

\section{Water Activity Determination}

Water activity was measured using a water activity meter (Novasina, Thermostanter Switzerland) calibrated with a standard sample with a known value (range 0.11-0.99). The experimental data were obtained using three replications.

\section{Antioxidant Capacity Assessment}

Preparation of Leaf Extracts. In the preparation of the extracts, five grams each of the dried leaf samples previously washed with water were used. The ratio between the sample and the solvent was 1:10 (w/v). Samples were homogenized using a blender with $50 \mathrm{~mL}$ of $95 \%$ ethanol as the solvent at room temperature. The resulting mixture was transferred into a small beaker, allowed to stand for an hour at room temperature and filtered using Whatman 42 filter paper.

$D P P H$ Assay. Using the DPPH radical scavenging assay, the antioxidant activity of all extracts was determined. Stock solution of DPPH $(22.5 \mathrm{mg} / \mathrm{L})$ was prepared using ethanol solvent and the initial absorbance was measured at 517 $\mathrm{nm}$ by UV-Vis spectrophotometer. To initiate the reaction, $0.1 \mathrm{~mL}$ of sample extract was added into $3.9 \mathrm{~mL}$ of DPPH solution. The resulting mixture was then shaken for 5 minutes and was allowed to stand at ambient temperature in the dark for one hour to complete the reaction of the cellular antioxidants with DPPH. Absorbance was read at $517 \mathrm{~nm}$ (Arbianti et al 2007) using 95\% ethanol as blank and the antioxidant activity was calculated from the 6-hydroxy-2,5,7,8tetramethylchroman-2-carboxylic acid (Trolox) standard curve. The amount of the sample necessary to react with one-half of the DPPH solution was expressed in terms of the micromole equivalents of the standard Trolox per gram of the fresh weight of sample or the Trolox units per gram or TE/100g. Analysis was done in triplicate.

$$
\frac{\mathrm{TE}}{100 \mathrm{~g}}=[(\mu \mathrm{TE})(\text { Volume of solvent }) /(\text { Mass of sample })](100)
$$


Effect of Drying Methods on the Physico-chemical Characteristics

\section{Statistical Analysis}

Data were compared on the basis of standard deviation of the mean values. SPSS package (Version 17.0, statistical software) was used to perform one-way analysis of variance (ANOVA) and Least Significant Difference test (LSD) at a 95\% confidence level $(p<0.05)$ to identify significant differences among samples within the evaluated parameters.

\section{RESULTS AND DISCUSSION}

\section{Moisture Content}

In the study, the drying methods significantly influenced the moisture content of the leaf samples (Table 1 \& Figure 1). Mechanical and solar drying of sp30 leaves had no appreciable difference. No significant difference can also be noted for both mechanical and sun drying of malunggay leaves. Among the different drying methods, solar drying noticeably had the highest moisture removal capacity having the lowest moisture content for all leaf samples. This is probably because solar drying had the highest drying temperature among others. The recorded solar drying temperature ranged from $33-70^{\circ} \mathrm{C}$ while $27-33^{\circ} \mathrm{C}$ for sun drying and $50^{\circ} \mathrm{C}$ for mechanical drying. On the other hand, sun dried leaves consistently obtained the highest moisture content thus had the lowest moisture removal capacity. This could be due to the lower temperature and longer drying time in sun drying method. According to Yousif et al (1999), longer drying time causes faster rate of water removal on the surface of the leaf than the rate of diffusion to the surface.

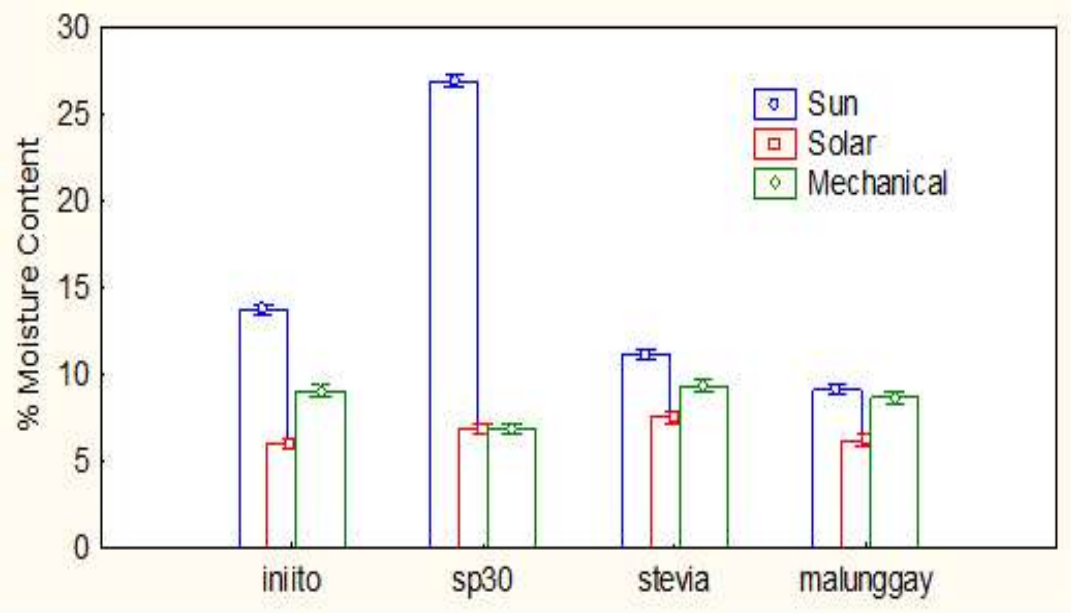

Figure 1. Effect of drying methods on moisture content of the different leaf samples 


\section{Rehydration Ratio}

The rate and extent of rehydration can be an indicator of the quality of the dried product. Rehydration capacity of a dried food material must be maximized. Rehydration rate is maximized when cellular and structural disruptions such as shrinkage are minimized (Lee et al 2007).

Statistically, drying methods had significantly affected the rehydration characteristic of both iniito and sp30 leaves but not so much with stevia and malunggay leaves (Table 1 \& Figure 2). For iniito and $s p 30$ leaves, maximum rehydration ratio was observed using solar drying method and minimum using sun drying method. This behavior might be due to the fact that much higher temperature in solar drying than in mechanical and sun drying allows more protoplasmic protein coagulation destroying the osmotic properties of cell membrane resulting to less swelling of the dried leaf samples (Vega-Galvez et al 2008). In addition, the rate of moisture removal at a higher drying temperature is faster and promotes lesser shrinkage of the dried samples. Solar drying therefore in this case causes fewer structural changes and fewer changes to product's hydrophilic properties than the other drying processes. In the case of sun drying, leaf samples underwent severe unfavorable drying condition such that it obtained the lowest rate of moisture removal resulting in the lowest degree of rehydration.

\section{BulkDensity}

Statistical analysis revealed that for bulk density, sun drying substantially differed from both mechanical and solar drying. No substantial difference at all was observed for mechanical and solar drying. Bulk density was found to be maximum in all sun dried leaves (Table 1 \& Figure 3). This indicates that solar and mechanically dried leaves were lighter thus easier to transport because of reduced weight and volume.

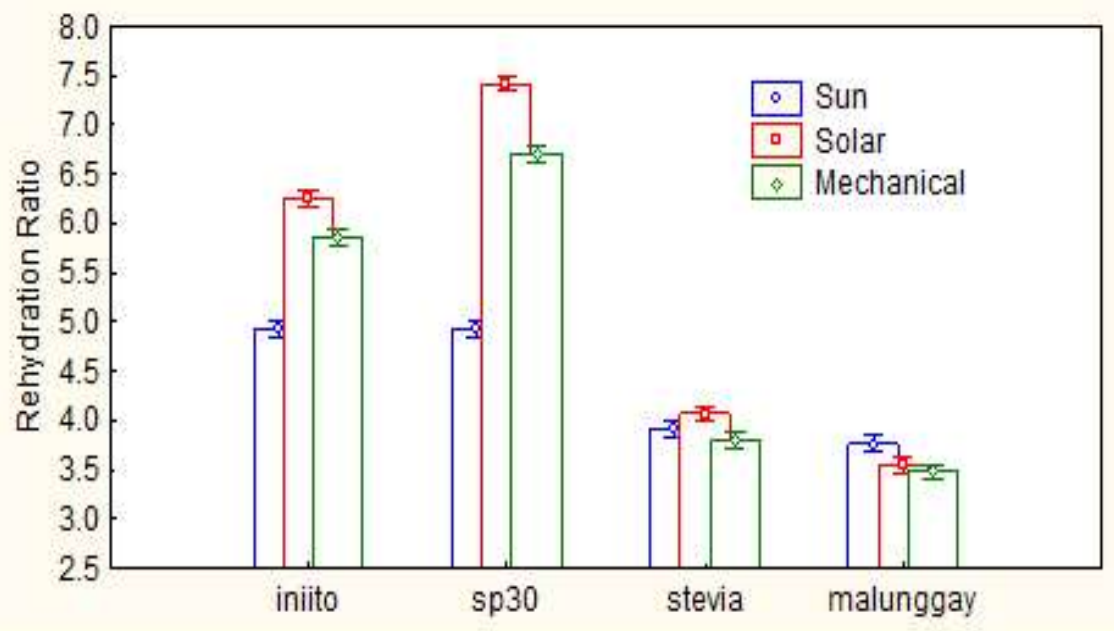

Figure 2. Effect of drying methods on the rehydration ratio of the different leaf samples 
Effect of Drying Methods on the Physico-chemical Characteristics



Figure 3. Effect of drying methods on bulk density of the different leaf samples

\section{Non-Enzymatic Browning (NEB)}

Browning of the different leaf samples was significantly affected by the drying methods. It was observed that the solar dried iniito, sp 30 and stevia leaves had the highest NEB exhibited whereas the mechanically dried samples of sp30, stevia, and malunggay had the lowest (Table 1 \& Figure 4). Browning in mechanically and sun dried iniito leaves had no appreciable difference as well as the browning in mechanically and solar dried stevia leaves. Since the browning reaction in food is heavily temperature and moisture-dependent, the higher degree of non-enzymatic browning occurring during solar drying was expected. Findings were in agreement with the reports of Kim et al 2007 and Son and Lee 2011.

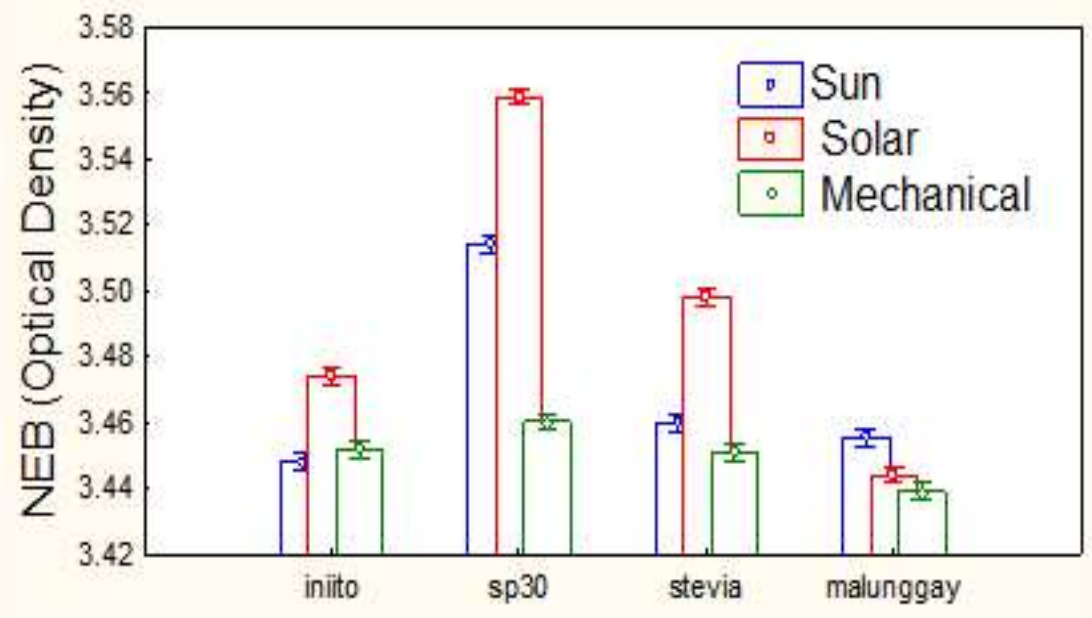

Figure 4. Effect of drying methods on non-enzymatic browning of the leaf samples 
Non-Enzymatic Browning (NEB)

Drying methods caused noticeable impact on the total chlorophyll content of both sp30 and malunggay leaf samples. No considerable effect however was observed on that of iniito and stevia leaves. It was found out that chlorophyll content was higher in mechanical drying and least in sun and solar drying (Table 1 \& Figure 5). Chlorophyll is heat sensitive and easily degraded in dried foods. Its retention also decreases as temperature and moisture is increased (Shih et al 2009). In the study, mechanical drying had the lowest drying temperature resulting to higher chlorophyll content. With higher drying temperature and higher moisture content of solar and sun drying respectively, lower chlorophyll content was obtained.

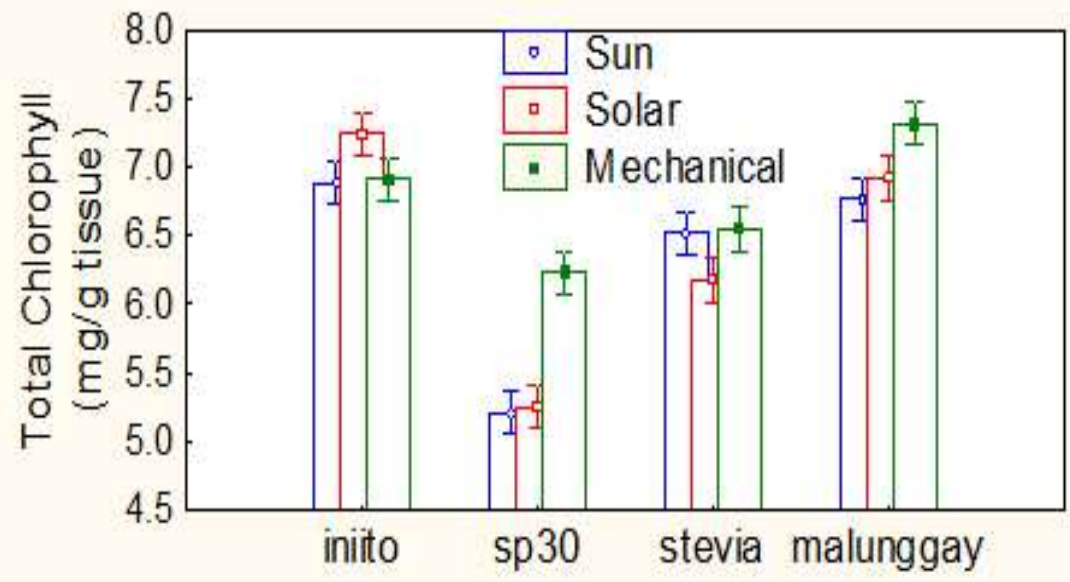

Figure 5. Effect of drying methods on the total chlorophyll content of the leaf samples

\section{Water Activity}

The different drying methods had significant influence on the water activity of the different leaf samples. As presented in Table 1 \& Figure 6, solar drying consistently had the lowest water activity attained across leaf samples while sun drying had the highest. According to Fontana (2008), there is no observable microbial proliferation at water activity below 0.6 . Based on the water activity values obtained in the study, all dried leaves except for sun dried sp30 leaves were within the minimum and safest water activity value required for any food product. 
Effect of Drying Methods on the Physico-chemical Characteristics

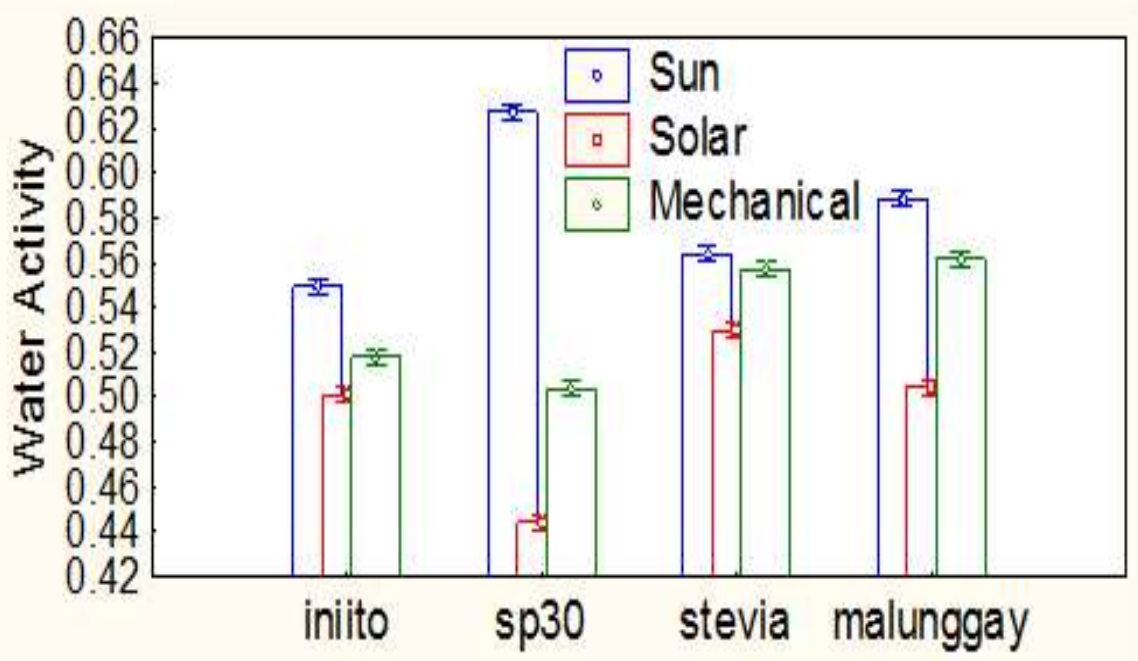

Figure 6. Effect of drying methods on the water activity of the different leaf samples

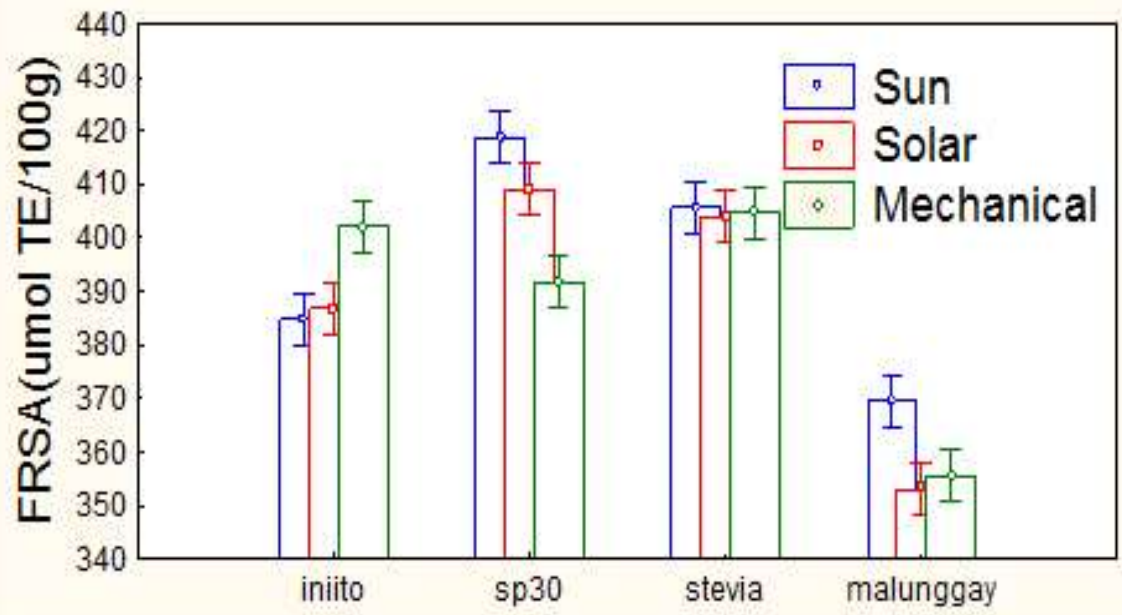

Figure 7. Effect of drying methods on free radical scavenging activity of the leaf samples

\section{Antioxidant Capacity}

The antioxidant capacity of the different dried leaf samples was determined by DPPH assay. DPPH has been widely used to evaluate the free radical scavenging activity of various antioxidant substances. DPPH is a stable free radical which gives rise to the deep violet color in ethanol solution, characterized by an absorption band centered at about $520 \mathrm{~nm}$. In the DPPH assay, the antioxidants which can donate hydrogen are able to reduce stable DPPH radical to the yellow 
colored, non-radical form of DPPH-H (Youssef \& Mokhtar 2014). In the study, maximum antioxidant capacity was observed in mechanically dried leaves of iniito and in sun dried leaves of sp30, stevia, and malunggay. Statistical analysis however revealed no apparent difference between solar and sun drying methods.

Table 1. Least Significant Difference test of the means of the different parameters analyzed

\begin{tabular}{|c|c|c|c|c|c|c|c|}
\hline $\begin{array}{l}\text { Leaf } \\
\text { Sample }\end{array}$ & $\begin{array}{c}\text { Moisture } \\
\text { Content } \\
(\%)\end{array}$ & $\begin{array}{c}\text { Rehydration } \\
\text { Ratio }\end{array}$ & $\begin{array}{c}\text { Bulk } \\
\text { Density } \\
(\mathrm{g} / \mathrm{mL})\end{array}$ & $\begin{array}{c}\text { Non } \\
\text { Enzymatic } \\
\text { Browning }\end{array}$ & $\begin{array}{c}\text { Total } \\
\text { Chlorophyll } \\
\text { Content } \\
\text { (g/mg } \\
\text { tissue) } \\
\end{array}$ & $\begin{array}{l}\text { Water } \\
\text { Activity }\end{array}$ & $\begin{array}{c}\text { Antioxidant } \\
\text { Capacity } \\
\text { ( } \mu \text { molTE/100 g) }\end{array}$ \\
\hline \multicolumn{8}{|l|}{ Iniito } \\
\hline SUD & $13.685^{a}$ & $4.917^{c}$ & $0.382^{a}$ & $3.448^{c}$ & $6.884^{\text {ns }}$ & $0.550^{a}$ & $384.776^{b c}$ \\
\hline SOD & $6.003^{c}$ & $6.258^{a}$ & $0.352^{b c}$ & $3.474^{a}$ & $7.241^{\mathrm{ns}}$ & $0.501^{c}$ & $386.775^{b}$ \\
\hline MED & $9.039^{b}$ & $5.864^{b}$ & $0.363^{\mathrm{ab}}$ & $3.452^{\mathrm{bc}}$ & $6.910^{\text {ns }}$ & $0.518^{b}$ & $402.199^{a}$ \\
\hline \multicolumn{8}{|l|}{ sp30 } \\
\hline SUD & $26.870^{a}$ & $4.917^{c}$ & $0.437^{a}$ & $3.514^{c}$ & $5.207^{b c}$ & $0.627^{a}$ & $418.766^{a b}$ \\
\hline SOD & $6.833^{b c}$ & $7.420^{a}$ & $0.359^{b}$ & $3.559^{a}$ & $5.254^{b}$ & $0.444^{c}$ & $409.055^{b c}$ \\
\hline MED & $6.832^{c}$ & $6.704^{b}$ & $0.325^{b c}$ & $3.460^{b}$ & $6.233^{a}$ & $0.504^{b}$ & $391.631^{c}$ \\
\hline \multicolumn{8}{|l|}{ Stevia } \\
\hline SUD & $11.095^{a}$ & $3.911^{\mathrm{ab}}$ & $0.356^{\mathrm{ns}}$ & $3.460^{b}$ & $6.518^{\text {ns }}$ & $0.564^{a}$ & $405.627^{\mathrm{ns}}$ \\
\hline SOD & $7.526^{c}$ & $4.067^{a}$ & $0.333^{\text {ns }}$ & $3.498^{a}$ & $6.174^{\text {ns }}$ & $0.530^{c}$ & $403.913^{\text {ns }}$ \\
\hline MED & $9.310^{b}$ & $3.804^{b c}$ & $0.328^{\text {ns }}$ & $3.45^{b c}$ & $6.548^{\text {ns }}$ & $0.557^{b}$ & $404.770^{n s}$ \\
\hline \multicolumn{8}{|c|}{ Malunggay } \\
\hline SUD & $9.105^{a}$ & $3.758^{a}$ & $0.343^{\text {ns }}$ & $3.455^{a}$ & $6.768^{\mathrm{bc}}$ & $0.588^{a}$ & $369.637^{a}$ \\
\hline SOD & $6.188^{c}$ & $3.536^{b}$ & $0.309^{n s}$ & $3.444^{b}$ & $6.919^{b}$ & $0.505^{c}$ & $353.077^{c}$ \\
\hline MED & $8.652^{b}$ & $3.475^{b c}$ & $0.338^{\mathrm{ns}}$ & $3.439^{b c}$ & $7.320^{a}$ & $0.562^{b}$ & $355.641^{b c}$ \\
\hline
\end{tabular}

SUD,sun dried; SOD, solar dried; MED, mechanically dried; values are expressed as means of 3 measurements

Means within leaf sample having the same superscript letter/s in a column are not significantly different at $p<0.05$

\section{CONCLUSIONS}

The study was conducted to determine the effect of drying methods on the physico-chemical characteristics and antioxidant capacity of taro (Colocasia esculenta), sweet potato (Ipomea batatas, I), stevia (Stevia rebaudiana), and malunggay (Moringa oleifera) leaves. Moisture content, rehydration ratio, bulk density, water activity, total chlorophyll content, antioxidant capacity, and nonenzymatic browning of the leaf samples dried using solar, mechanical and sundrying were determined and compared.

Solar drying had the highest moisture removal capacity, rehydration ratio and water activity reduction while sun drying had the least. However solar drying had the highest observed degree of non-enzymatic browning. Minimum bulk density was attained using solar and mechanical drying while maximum using sun drying. 
Effect of Drying Methods on the Physico-chemical Characteristics

In terms of chlorophyll content, mechanical drying had the highest. No apparent difference between solar and sun drying methods was observed on the chlorophyll retention and antioxidant capacity of the leaf samples.

Generally, the drying methods have significant and variable effects on the physico-chemical and antioxidant properties of the different leaf samples evaluated. Variable effects of the different drying methods include little or no change, significant declines or enhancement of the leaves' physico-chemical and antioxidant attributes.

\section{RECOMMENDATION}

Other drying methods are recommended to be conducted. Based on the study, dried taro, sweet potato, malunggay and stevia leaves can be very good sources of biologically active components with high antioxidant activity and have potential role of functional or nutraceutical foods. Thus, it is recommended to understand further the dynamics involved in the effect of drying on the physico-chemical and functional properties of these leaves. Storage study of the dried leaf samples is also recommended.

\section{ACKNOWLEDGMENT}

The authors would like to thank the Philippine Higher Education Research Network (PHERNET) of the Commission on Higher Education(CHED) for funding the research.

\section{REFERENCES}

Association of Official Analytical Chemists. 1990. Official Methods of Analysis of AOAC International.(15th edn). Author, Maryland, USA.

Doymaz I. 2010. Drying of thyme (Thymus Vulgaris L.) and selection of a suitable thin- layer drying model. Journal of Food Processing Preservation, 35:1745 4549.

Fahey JW. 2005. Moringa Oleifera: Review of medical evidences for its nutritional, therapeutic, and prophylactic properties Part 1. Trees for Life Journal, 1:5.

Gisleine EC, Abdol HA, Caudio CA, Letícia de AFF, Gilson T, Mirian HT, Wilson EF, \& Roberto BB. 2006. Investigation of the tolerability of oral Stevioside in Brazilian hyperlipidemic patients. Brazilian Archives of Biology and Technology, 49:583587

Islam S. 2006. Sweetpotato leaf: Its potential effect on human health and nutrition," Journal of Food Science, 71:R13R21.

Kaushal M. 2013. Effect of blanching on nutritional quality of dehydrated colocasia leaves. Indian Journal of Natural Products and Resources, 4(2):161-164.

Kim HR, Seog EJ, Lee JH \& Rhim JW. 2007. Physicochemical properties of onion powder as influenced by drying methods. Journal of the Korean Society of Food Science and Nutrition, 36: 342-347.

Lee MJ, Seog EJ, Lee JH. 2007. Physicochemical properties of chaga (Inonotus obliquus) mushroom powder as influenced by drying methods. Journal of Food Science and Nutrition, 12:40-45. 
Negi PS \& Roy SK. 2001. Effect of drying conditions on quality of green leaves during long term storage. Food Research International, 34:283-287

Shih MC, Kuo CC \& Chiang WC. 2009. Effects of drying and extrusion on colour, chemical composition, antioxidant activities and mitogenic response of spleen lymphocytes of sweet potatoes. Food Chemistry, 117:114-121.

Son SM, Moon KD \& Lee CY. 2001. Inhibitory effects of various antibrowning agents on apple slices. Food Chemistry, 73: 23-30.

Ranganna S. 1986. Handbook of analysis and quality control for fruits and vegetable products (2nd edn, pp497-528). McGraw Hill, New Delhi.

Vega-Gálvez A, Lemus-Mondaca R, Bilbao-Sáinz C, Fito P \& Andrés A. 2008. Effect of air drying temperature on the quality of rehydrated dried red bell pepper (var.Lamuyo). Journal of Food Engineering, 85:42-50.

Yousif AN, Scaman CH, Durance TD \& Girard B. 1999. Flavor volatiles and physical properties of vacuum-microwave- and air-dried sweet basil (Ocimum basilicum L.). Journal of Agricultural Food Chemistry, 47:4777-4781.

Youssef KM \& Mokhtar SM .2014. Effect of Drying Methods on the Antioxidant Capacity, Color and Phytochemicals of Portulaca oleracea L. Leaves. Journal of Nutrition and Food Sciences, 4:322. doi:10.4172/2155-9600.1000322 